\title{
Molecular Markers and Phylogenetic Analysis of UPMT27, a Field Isolate of the Malaysian Fowl Adenovirus Associated with Inclusion Body Hepatitis
}

\author{
Salisu Ahmed ${ }^{1,4}$, Abdul Razak Mariatulqabtiah ${ }^{1,3}$, Mohd Hair Bejo ${ }^{2,3}$, \\ Abdul Rahman Omar ${ }^{2,3}$, Aini Ideris ${ }^{2,3}$ and Nurulfiza Mat Isa ${ }^{1,3 *}$ \\ ${ }^{1}$ Faculty of Biotechnology and Biomolecular Sciences, Universiti Putra Malaysia, 43400 UPM, Serdang, \\ Selangor, Malaysia \\ ${ }^{2}$ Faculty of Veterinary Medicine, Universiti Putra Malaysia, 43400 UPM, Serdang, Selangor, Malaysia \\ ${ }^{3}$ Institute of Bioscience, Universiti Putra Malaysia, 43400 UPM, Serdang, Selangor, Malaysia \\ ${ }^{4}$ Department of Science Laboratory Technology, Jigawa State Polytechnic, 7040 Dutse, Jigawa state, Nigeria
}

\begin{abstract}
Inclusion body hepatitis (IBH) is considered one of the re-emerging diseases of avian virus that causes economic damage worldwide. IBH is caused by different serotypes of fowl adenovirus (FAdV), and most of the FAdV cases in Malaysia are related to the serotype $8 \mathrm{~b}$. The objective of this study was to determine the molecular markers of UPMT27 Malaysian FAdV isolate and to identify the evolutionary relationship through the phylogenetic approach. Propagation of the isolate was made in embryonated chicken eggs and chicken embryo liver (CEL cells) before it was subjected to viral DNA extraction. Both the fiber and hexon genes of the isolate were amplified and sequenced. The sequences were aligned with the published FAdV sequences. The results showed $100 \%$ identity between UPMT27 and the previous Malaysian

ARTICLE INFO

Article history:

Received: 20 April 2020

Accepted: 11 November 2020

Published: 22 January 2021

DOI: https://doi.org/10.47836/pjst.29.1.29

E-mail addresses:

Sahmed@jippoly.edu.ng (Salisu Ahmed)

mariatulqabtiah@upm.edu.my (Abdul Razak Mariatulqabtiah)

mdhair@upm.edu.my (Mohd Hair Bejo)

aro@upm.edu.my (Abdul Rahman Omar)

aiini@upm.edu.my (Aini Ideris)

nurulfiza@upm.edu.my (Nurulfiza Mat Isa)

* Corresponding author isolates. A phylogenetic study showed that UPMT27 was closely related to the previous Malaysian isolates. Interestingly, the substitution of the amino acids was consistent between the Malaysia isolates of both fiber protein at positions 72 (Serine -serine), 101 (Alanine -alanine), 125 (Glycine-glycine), and hexon protein 85 (Serine-serine) 160 (Glutamate-glutamate) and 205 (Alanine-alanine) respectively. It
\end{abstract}


appeared that the amino acid variations were the indicators for genetic diversity. Thus, these findings provide information on the evolutionary relationship between FAdV subtypes for IBH prevention.

Keywords: Amino acids, fiber, fowl adenovirus, hexon, inclusion body hepatitis, PCR, phylogenetic analysis

\section{INTRODUCTION}

The global spread of fowl adenovirus (FAdV) cases is related to the varieties of the virus infection. These disease outbreaks cause significant economic lost in the poultry trade (Li et al., 2017). Commercial farm birds especially broilers are susceptible to FAdV infection. FAdV is characterized by a wide range of virulence (Mcferan \& Smyth, 2000). FAdV has been classified as a member of genus of aviadenovirus and divided into 5 molecular subgroups (designated as FAdV -A to E). The virus is categorized into twelve serotypes (Serotype $1\{\mathrm{CELO}\}, 2,3,4,5,6,7,8 \mathrm{a}, 8 \mathrm{~b}, 9$ and 11) based on their restriction enzyme digest patterns, phylogenetic relationships, pathogenicities, neutralizations, molecular organizations, and recombinant potentials

The pathogenicity of the virus is associated with a wide range of avian diseases. Serotype 1 is associated with gizzard erosion and ulceration (GUE) (Niu et al., 2016), while serotype- 4 is the pre-dominant causative agent of hydropericadium syndrome (HHS) (Zhang et al., 2018). In addition, serotypes 2, 3, 8a, 8b, 9 and 11 are the etiological agents of inclusion body hepatitis (IBH) (Gupta et al., 2018).

Serotype $8 \mathrm{~b}$ is a causative agent of most cases of inclusion body hepatitis (IBH) in all Asian countries and in South America, Australia, North America, Canada, and South Africa (Morshed et al., 2017).

In Malaysia, cases of IBH among commercial chickens is rising exponentially and a vaccine against IBH is not yet available to prevent the outbreaks (Juliana et al., 2014). Primary cells derived (chicken embryo liver cells) from 13-14 days SPF chicken embryonated eggs are frequently used for virus propagation and attenuation (Mansoor et al., 2011). IBH cases in Malaysia, were first isolated in 2005 from commercial broilers chickens with high mortality and poor broiler performance due to serotype $8 \mathrm{~b}$ and caused significant impact to the poultry industry (Norfitriah et al., 2018). Since then, the outbreaks have also been reported in several states of Malaysia involving major poultry producing areas (Norina et al., 2016).

Previous studies revealed that the fiber and hexon proteins were the major structural proteins of fowl adenovirus, in which the serotype, group and subgroup-specific antigenic determinants were located as demonstrated in the virus virion surface (James \& Edward, 2011). Subsequently, the major antigenic determinant was located on the fiber and hexon genes, the virus encoded those proteins during viral replication, which penetrated into the 
nucleus of host cells (Wang \& Zhao, 2019). Nevertheless, there is a scanty of information on the roles of these proteins. It has been speculated that the fiber protein may play a vital role for virus attachment and internalization of the virus into the host cell (Wang \& Zhao, 2019).

Among the three major structural proteins, hexon comprises the largest portion of the virus protein and is divided into two major parts namely conserved and variable loops. Conserved regions are further divided into two fragments namely P1 and P2 located in the internal capsid side and play a major role in structural stability of hexon protein. The external capsid side of hexon forms three intertwined loops known as L1, L2 and L4 that are not conserved and exposing different surfaces between serotypes to form type-specific epitopes Research indicates, that the L1 loop was found to be longest and complex in mastadenovirus while L3 loop buried internally and more conserved to stabilize the interface between $\mathrm{P} 1$ and $\mathrm{P} 2$ conserved regions. The antigenic specificity region or epitope is situated in the hypervariable region in loop 1 and loop 2 of the hexon. It is the predominant target for the induction of serotype specific neutralizing antibodies. Previous study indicates that the hexon gene is associated with the FAdV pathogenicity that plays a major role in virus neutralization antibody (Rux \& Burnett, 2003). It has been reported that amino acid substitution in the variable region of L1 of a cell culture-based adapted FAdV strain resulted in complete attenuation (Majdi \& Hair-Bejo, 2015).

The fiber protein is one of the major surface-exposed capsid structure of adenovirus, which is responsible for virus antigenicity and harbour type-specific epitopes. It is characterized by the formation of projection and bound noncovalently to the penton base involved in virus entry into the host cell and implicated in the variation of virulence of FAdVs. The fiber protein is divided into 3 domains which involve tail, shaft, and head or knob comprising some specific features (Grgić et al., 2013).

The fiber protein, specifically the head or the knob region is characterized as a receptorbinding domain and the fiber molecule is a critical factor associated with the infection properties of $\mathrm{AdV}$, such as alterations in tissue tropism and virulence. In addition, it had been established that an amino acid substitution in the fiber protein of a FAdV serotype could cause a difference in pathogenicity (Pallister et al., 1996). The shaft domain is located between the tail and head of the fiber protein. The unique special, feature in the shaft domain of human adenovirus is the detection of 22 pseudo-repeats" of 15 amino acid residues, most with a Proline $(\mathrm{P})$ or Glycine $(\mathrm{G})$ in a common position and with common substituting of hydrophobic and hydrophilic amino acids (aa) and play an important role in the $b$-strand formation. The shaft region constitutes the largest portion of the fiber protein its specific role toward virulence was not established but, the presence of corresponding amino acid motif "VYPF" at position (55-56 amino acid), involved in the penton base interaction (Grgić et al., 2014). 
The penton protein enhances interactions with cellular components and the virusneutralizing antibody (Wang \& Zhao, 2019).

Therefore, the objectives of this study were to identify amino acid variations between the UPMT27 isolate and other previous isolates and to establish its evolutionary relationships with other FAdV isolates worldwide.

\section{MATERIALS AND METHODS}

\section{Viral Strain}

FAdV UPMT27 was isolated from the liver of a 27-day old broiler chicken in Tawau, Sabah, Malaysia in 2017 outbreak with 2\% mortality. The infected broiler chicken exhibited classical IBH clinical signs such as severe depression, ruffled feathers, and crouching positions. On necropsy, the affected chickens had pale, swollen, friable, hemorrhagic livers with focal to extensive necrosis, gizzard erosions and basophilic intranuclear inclusion bodies in hepatocytes (Popowich et al., 2018).

\section{Preparation of Chicken Embryo Liver Cells (CELs)}

Primary chicken embryo liver (CEL) cells were derived from 13-15 days old SPF eggs based on Soumyalekshmi et al. (2014) with slight modifications. The livers of SPF embryonated chicken eggs were aseptically removed and washed twice with $\mathrm{x} 1 \mathrm{ml}$ of PBS, $\mathrm{pH}$ 7.4. The liver tissues were gently minced and transferred into a sterile beaker, $0.25 \%$ trypsin-EDTA solution was added, and the mixture shaken for 20 minutes. The trypsinised livers cells were gently decanted and sterile gauze tied to a beaker was used to filter the liver cells. Growth medium DMEM (High glusose, L-glutamine; sodium pyruvate, Biosera) supplemented with $10 \%$ foetal bovine serum (FBS; Hyclone) and $1 \mathrm{x}$ antibiotics penicillin streptomycin solution was added to the filtrate at the rate of $10 \mathrm{ml} / 100 \mathrm{ml}$ to stop the activity of trypsin. Subsequently the cells were centrifuged at $350 \mathrm{~g}$ for 5 minutes at $4^{\circ} \mathrm{C}$. The supernatant was decanted, and growth medium was added to the cell pellet. The cell concentrations were adjusted to $5.0 \times 10^{6}$ cell $/ \mathrm{ml}$ of the medium and $5 \mathrm{ml}$ of the cell suspension were seeded in $25 \mathrm{~cm}^{2}$ tissue culture flasks until a $70 \%$ monolayer was formed. Tissue culture flasks containing complete monolayers were infected with $0.1 \mathrm{ml} \mathrm{FAdV} \mathrm{(UPMT27),} \mathrm{maintained}$ at $37^{\circ} \mathrm{C}$ in a $5 \% \mathrm{CO}_{2}$ incubator and observed for cytopathic effect (CPE) daily. After CPEs was established, the flasks were freeze- thawed 3 times and the cells were transferred into $50 \mathrm{ml}$ centrifuge tubes and centrifuge at $350 \mathrm{xg}$ for $5 \mathrm{~min}$ and the supernatants were gently harvested by pipette and stored at $-20^{\circ} \mathrm{C}$ until use.

\section{Extraction of Virus Genomic DNA}

The FAdV genomic DNA extraction was carried out using (Analytikjena innu PREP viral, Germany). DNA extraction was performed in a fresh $2.0 \mu 1$ tube. A mixture containing 
$200 \mu \mathrm{l}$ of CBV/ carrier mix, $200 \mu \mathrm{l}$ of viral supernatant and $20 \mu 1$ of the proteinase $\mathrm{K}$ were vigorously mixed and incubated at $70^{\circ} \mathrm{C}$ (water bath) for 10 minutes. After the incubation, $400 \mu 1$ of the Binding solution (SBS) were added to the lysate cells and vortexed. The mixture was applied to the spin filter and centrifuged at $10,000 \mathrm{~g}$ for 5 minutes. The filtrate was discarded, and the spin filter was placed in a new $2.0 \mathrm{ml}$ receiver tube. Then $650 \mu \mathrm{l}$ washing solution (LS) was added to the spin column and centrifuged at $10,000 \mathrm{~g}$ for 5 minutes. The steps were repeated once and the spin filter was placed in a new $2.0 \mathrm{ml}$ receiver tube and centrifuged at 10,000g for 5 minutes. The receiver tube was also discarded to remove all traces of ethanol. The spin filter was placed into a new $1.5 \mathrm{ml}$ elution tube. Then, $60 \mu 1$ of preheated nuclease free water were added into the column and it was incubated at room temperature for 2 minutes and subsequently centrifuged at $8,000 \mathrm{xg}$ for 1 minute. The concentration of the genomic DNA was quantified by spectrophotometry (Beckman, USA).

\section{DNA Amplifications of Fiber and Hexon Genes}

The DNA amplifications of the fiber and hexon gene for the detection of FAdV were performed using MyTaq ${ }^{\mathrm{TM} M i x}$ (Bioline, UK) based on the recommended protocol. Primers were designed based on FAdV accession numbers KT862811 retrieved from the GenBank (Marek et al., 2016) for the hexon and the fiber genes, respectively. HexonF/ HexonR (HexonF: 5'-ATG GCC GCG TTT ACA CC-3' and HexonR: 5'-TTA CAC AGC GTT ACC GG -3') and FiberF/FiberR (FiberF: 5'-ATG GCG ACC TCG ACT CC-3' and FiberR: 5'-TTA AGG AGC GTT GGC GG-3') were used to amplify the complete hexon gene and the partial fiber gene.

PCR amplification was performed on a PCR thermocycler (C1000 Touch $^{\mathrm{TM}}$ Thermal Cycler (BIO-RAd, USA). The PCR mixture of $50 \mu$ containing $2 \mu 1$ (10 pmol) of both forward and reverse primers, $25 \mu \mathrm{l} \mathrm{MyTaq}{ }^{\mathrm{TM} M i x, ~} 1 \mu \mathrm{l} / \mathrm{ng}$ DNA template and $22 \mu \mathrm{l}$ nuclease-free water was subjected to the following thermal condition protocol: $95^{\circ} \mathrm{C}$ for $1 \mathrm{~min}$, followed by 30 cycles of $95^{\circ} \mathrm{C}$ for $15 \mathrm{~s}, 51^{\circ} \mathrm{C}-60^{\circ} \mathrm{C}$ (Gradient) for $15 \mathrm{~s}$, and $72^{\circ} \mathrm{C}$ for $1 \mathrm{~min}$, followed by a final elongation step of $1 \mathrm{~min}$ at $72^{\circ} \mathrm{C}$. Agarose gel electrophoresis $(1 \%(\mathrm{w} / \mathrm{v})$ agarose gel) was used to examine the PCR products of the isolate under study together with the positives controls isolates for hexon gene (KY305955) and fiber gene (KY305945) at $125 \mathrm{~V}$ for $40 \mathrm{~min}$ (iNtRON). The gel was then visualized under Gel doc (transillumination UV BIO- RAD). PCR products of the expected lengths, of fiber (882 bp) and hexon (2900 bp) were purified using a kit (Analytikjena innu PREP viral, Germany).

The PCR product of the positive samples was then subjected to the purification process. A mixture of $50 \mu 1$ of PCR product and $500 \mu$ l of binding buffer were mixed in a reaction tube and vortexed. The mixture was transferred into a spin filter and centrifuged at 11,000 $\mathrm{x} g$ for 3 minutes and flow-through was discarded. The spin filter was placed into a new elution tube, $50 \mu 1$ of the RNase- free water were added directly onto the spin filter and 
incubated for 1 minute at room temperature. After the 1 minute incubation, the mixture was centrifuged at 11, $000 \mathrm{xg}$ for 1 minute. The purified PCR products were then sent for nucleotide sequencing using hexon and fiber primers (HexonF/HexonR) (FiberF/FiberR) respectively

\section{Nucleotide, Amino Acid Sequencing and Phylogenetic Analysis}

The nucleotide sequence results were assembled and examined using BioEdit (USA ver.6.0; Therapeutics, Ibis).

The nucleotide sequence determined were 882 bp-long, corresponds to 294 amino acid sequence covering the shaft region of the fiber gene. But only $558 \mathrm{bp}-$ long of the fiber gene were used for further nucleotide sequence analysis which correspond to position 30644 to 31232 in the fiber gene of the reference strain KT862811 (Marek et al., 2016) encompassing the shaft region of the fiber gene. Meanwhile, the nucleotide sequence used for hexon analysis were $2900 \mathrm{bp}$-long corresponds to 996 amino acid sequence covering the Loop 1 of the gene. But only 556 bp long of the hexon were used for further analysis which correspond to position 26377 to 26933 in the hexon gene of the reference strain KT862811 (Marek et al., 2016) encompassing the Loop 1 region of the hexon gene. UPMT27 isolates was aligned with the 28 and 27 published sequences for fiber and hexon respectively to identify the nucleotides homology among the FAdV strains. The fiber and the hexon gene sequences were successively submitted to the NCBI database GenBank and were given the following accession numbers for fiber (MT233531) and hexon (MT233532).

A total of 28 and 27 complete FAdV fiber gene (Table 1) and hexon gene (Table 2) sequences were aligned with the reference sequences retrieved from Genbank were used for the construction of the phylogenetic tree. All sequences were aligned by CLUSTAL W'. Distance-based neighbor joining phylogenetic trees were constructed using the Tamura-Nei model available in the program MEGA 6.0 with 1,000 bootstrap replicates used to evaluate them (Niu et al., 2016).

Nucleotide sequences of fiber and hexon genes generated from the UPMT27 and published FAdV isolates were translated into amino acids residues and analyse the similarity and variation of amino acid substitution between the isolate under study (UPMT27) and the published FAdV isolate.

\section{RESULTS}

DNA fragments of the expected lengths of the fiber gene $882 \mathrm{bp}$ (Figure 1) and hexon genes 2900 bp (Figure 2) were observed in the agarose gel. Nucleotide sequence analysis revealed that the isolate of this study had high nucleotide identity [E value $=0,99 \%$ identity] with the Malaysian isolates for fiber (KU517714, KY305954, KY305955 and KY305950) and hexon genes (KU517714, KY305954, KY305955, and KY305950) (Juliana et al., 2014; Norfitriah, 2018) 
Table 1

Fowl adenovirus fiber gene sequences retrieved from NCBI for phylogenetic analysis

\begin{tabular}{|c|c|c|c|c|}
\hline $\mathbf{S} / \mathbf{N}$ & Strain & Accession Number & Group* & Reference \\
\hline 1 & Strain 8b 764 & KT862811 & $\mathrm{E}$ & Marek et al., 2016 \\
\hline 2 & UPMT27* & MT233531 & $\mathbf{E}$ & This study \\
\hline 3 & UPM04217 & KU517714 & $\mathrm{E}$ & Juliana et al., 2014 \\
\hline 4 & UPM1137E15 & KY305953 & $\mathrm{E}$ & Norfitriah, 2018 \\
\hline 5 & UPM1137E10 & KY305955 & $\mathrm{E}$ & Norfitriah, 2018 \\
\hline 6 & UPM1137E5 & KY305954 & $\mathrm{E}$ & Norfitriah, 2018 \\
\hline 7 & UPM1137CEL35 & KY305956 & $\mathrm{E}$ & Norfitriah, 2018 \\
\hline 8 & UPM1137CEL25 & KY305950 & $\mathrm{E}$ & Norfitriah, 2018 \\
\hline 9 & UPM1137CEL10 & KY305957 & $\mathrm{E}$ & Norfitriah, 2018 \\
\hline 10 & QD2016 & MF577036 & $\mathrm{E}$ & Unpublished \\
\hline 11 & Strain $\mathrm{HG}$ & GU734104 & $\mathrm{E}$ & Grgić et al., 2011 \\
\hline 12 & SD1356 & MG712775 & $\mathrm{E}$ & Unpublished \\
\hline 13 & Vac-2005 & KT037704 & $\mathrm{E}$ & Unpublished \\
\hline 14 & VIC-2/430-06 & KT037705 & $\mathrm{E}$ & Unpublished \\
\hline 15 & NSW-5/100931 & KT037708 & $\mathrm{E}$ & Unpublished \\
\hline 16 & NZ-1/101151-1 & KT037709 & $\mathrm{E}$ & Unpublished \\
\hline 17 & ON NP2 & KP231537 & $\mathrm{D}$ & Slaine et al., 2016 \\
\hline 18 & HBQ12 & KM096545 & $\mathrm{D}$ & Zhao et al., 2015 \\
\hline 19 & MX95-S11 & KU746335 & $\mathrm{D}$ & Unpublished \\
\hline 20 & $\mathrm{CH} / \mathrm{HNJZ} / 2015$ & KU558760 & $\mathrm{C}$ & Unpublished \\
\hline 21 & AG234 & MK572850 & $\mathrm{C}$ & Unpublished \\
\hline 22 & HLJFAd15 & KU991797 & $\mathrm{C}$ & Unpublished \\
\hline 23 & Strain-340 & HE608155 & $\mathrm{B}$ & Marek et al., 2012 \\
\hline 24 & $40440-\mathrm{M} / 2015$ & MG953201 & B & Unpublished \\
\hline 25 & Isolate-340 & FR872928 & $\mathrm{B}$ & Marek et al., 2012 \\
\hline 26 & Strain-340 & KC493646 & B & Marek et al., 2013 \\
\hline 27 & Strain A-OTE & FN557183 & A & Marek et al., 2010 \\
\hline 28 & CELO & U46933 & A & Chiocca et al., 1996 \\
\hline
\end{tabular}

Note. UPMT27 * Indicate the isolate use in this present study Group*= FAdV grouping $(\mathrm{A}-\mathrm{E})$

Table 2

Fowl adenovirus hexon gene sequences retrieved from NCBI for phylogenetic analysis

\begin{tabular}{lllll}
\hline S/N & Strain & Accession Number & Group* & Reference \\
\hline 1 & Strain 8b 764 & KT862811 & E & Marek et al., 2016 \\
2 & UPM T27 & MT233532 & E & This study \\
3 & UPM04217 & KU517714 & E & Juliana et al., 2014 \\
4 & UPM1137E10 & KY911366 & E & Norfitriah, 2018 \\
5 & UPM1137E15 & KY911367 & E & Norfitriah, 2018 \\
\hline
\end{tabular}


Table 2 (continue)

\begin{tabular}{lllll}
\hline S/N & Strain & Accession Number & Group* & Reference \\
\hline 6 & UPM1137CEL15 & KY305953.1 & E & Norfitriah, 2018 \\
7 & UPM1137CEL 10 & KY305944.1 & E & Norfitriah, 2018 \\
8 & Strain HG & GU734104 & E & Grgić et al., 2011 \\
9 & SD16-116 & KY426984 & E & Niu et al., 2016 \\
10 & SD1356 & MG712775 & E & Huang et al., 2019 \\
11 & ID-HCL-038 & MG765468 & E & Unpublished \\
12 & USP-BR-420 & KY229168 & E & Unpublished \\
13 & Strain-764 & AF508958 & D & Meulemans et al., 2004 \\
14 & SD15-24 & KY426992 & D & Unpublished \\
15 & ON NP2 & KP231537 & D & Slaine et al., 2016 \\
16 & JL/1407 & KY012057 & D & Unpublished \\
17 & ZZ-Isolate & MN337322 & C & Unpublished \\
18 & HN/151025 & KU245540 & C & Unpublished \\
19 & SDSX1 & KY636400 & C & Unpublished \\
20 & SD1601/FAdV4 & MH006602 & C & Unpublished \\
21 & AG234 & MK572850 & C & Unpublished \\
22 & CH/GDYF/201706 & MK387062 & C & Unpublished \\
23 & CH/HNJZ/2015 & KU558760 & C & Unpublished \\
24 & CELO-CORR & MK572875 & A & Schachner et al., 2019 \\
25 & CELO & U46933A & A & Chiocca et al., 1996 \\
26 & Strain-340 & KC493646B & B & Marek et al., 2016 \\
27 & LYG & MK757473 & B & Unpublished \\
\hline
\end{tabular}

Note. UPMT27 * Indicate the isolate use in this present study Group*= FAdV grouping $(\mathrm{A}-\mathrm{E})$

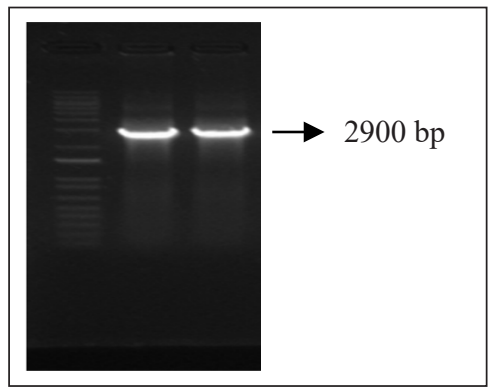

Figure 1. Amplification of hexon gene (2900 bp) using primer pair HexonF/HexonR of UPM T27 fowl adenovirus and reference isolates. M: DNA Ruler 1 $\mathrm{kb}^{+}$; Lane 1: Positive control [KY305955] (Norfitriah et al., 2018) and Lane 2: UPM T27.

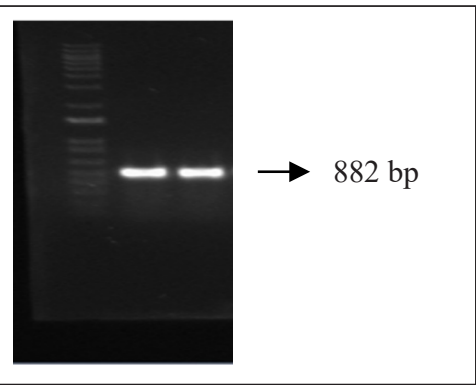

Figure 2. Amplification of fiber gene (882 bp) using primer pair FiberF/FiberR of UPMT27 fowl adenovirus and reference isolates. M: DNA Ruler 1 $\mathrm{kb}^{+}$; Lane 1: Positive control (KY305945) (Norfitriah et al., 2018) and Lane 2: UPMT27. 
Phylogenetic analyses based on the nucleotide sequences of the fiber and hexon genes revealed that UPMT27 was closely related to the Malaysian isolates (Juliana et al., 2014; Norfitriah, 2018) for fiber gene (Figure 3) and hexon gene (Figure 4) and shared common ancestors with FAdV serotypes $8 \mathrm{~b}$ under group $\mathrm{E}$

The multiple sequence alignment in the fiber gene shows that UPMT27 and Malaysian isolates (KU517714, KY305954, KY305955 and KY305950) (Juliana et al., 2014; Norfitriah, 2018) exhibit identical patterns of amino acid substitution at positions 72

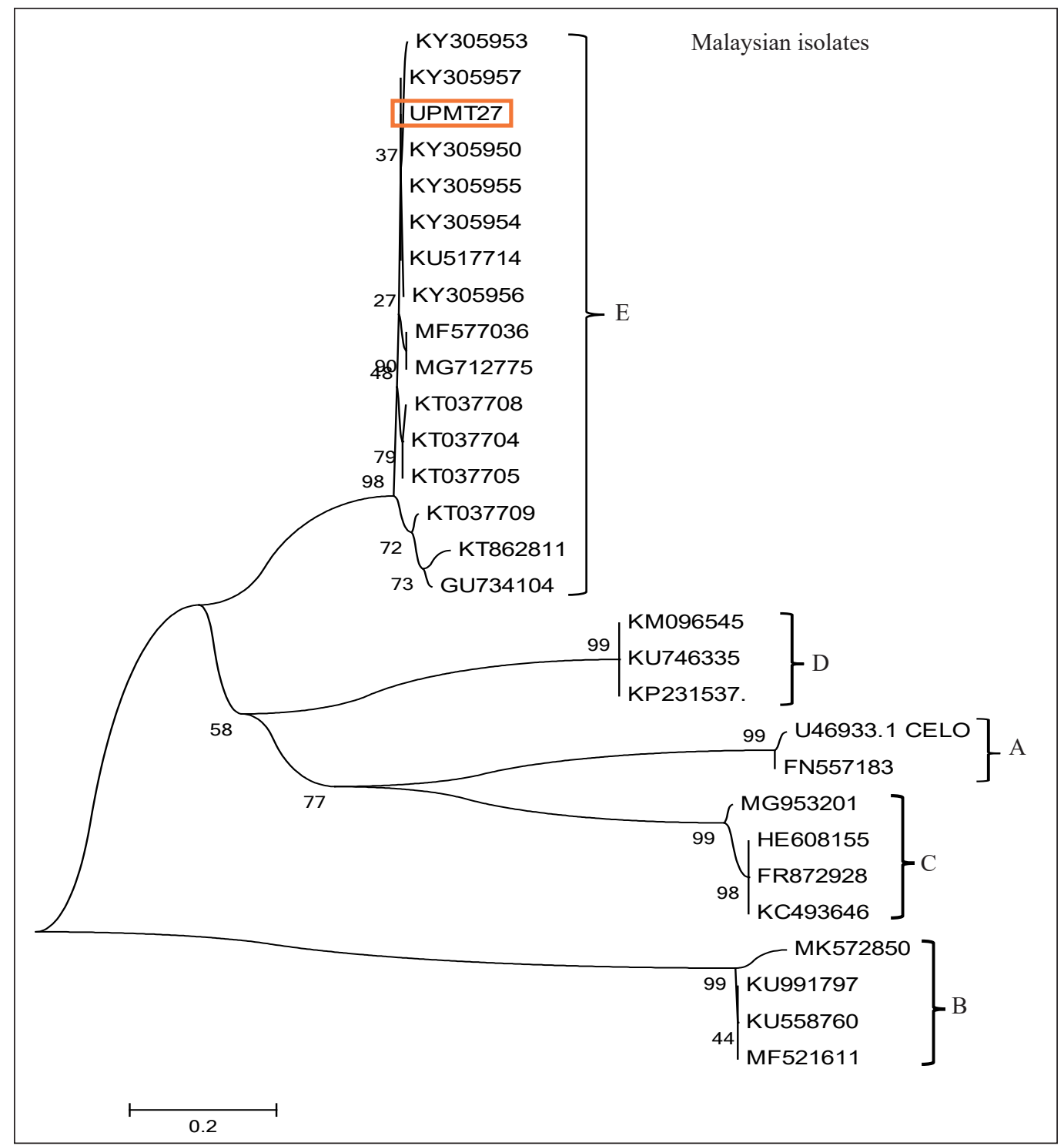

Figure 3. Sequence identity and phylogenetic analysis of partial fiber gene based on the 558 nucleotide bases in shaft region with 28 references isolates are labeled. At major nodes are indicated bootstrap values. UPMT27 is in red box 
(Serine-serine), 101 (Alanine -alanine), 125 (Glycine-glycine) respectively (Table 3). The result shows consistent amino acid substitution between UPMT27 and reference isolate KT862811 (Marek et al., 2016).

However, multiple sequence alignment of amino acids of the hexon gene shows that UPMT27 and Malaysian isolates (KU517714, KY305954, KY305955, and KY305950) (Juliana et al., 2014; Norfitriah, 2018) exhibit similar pattern of amino acid substitution

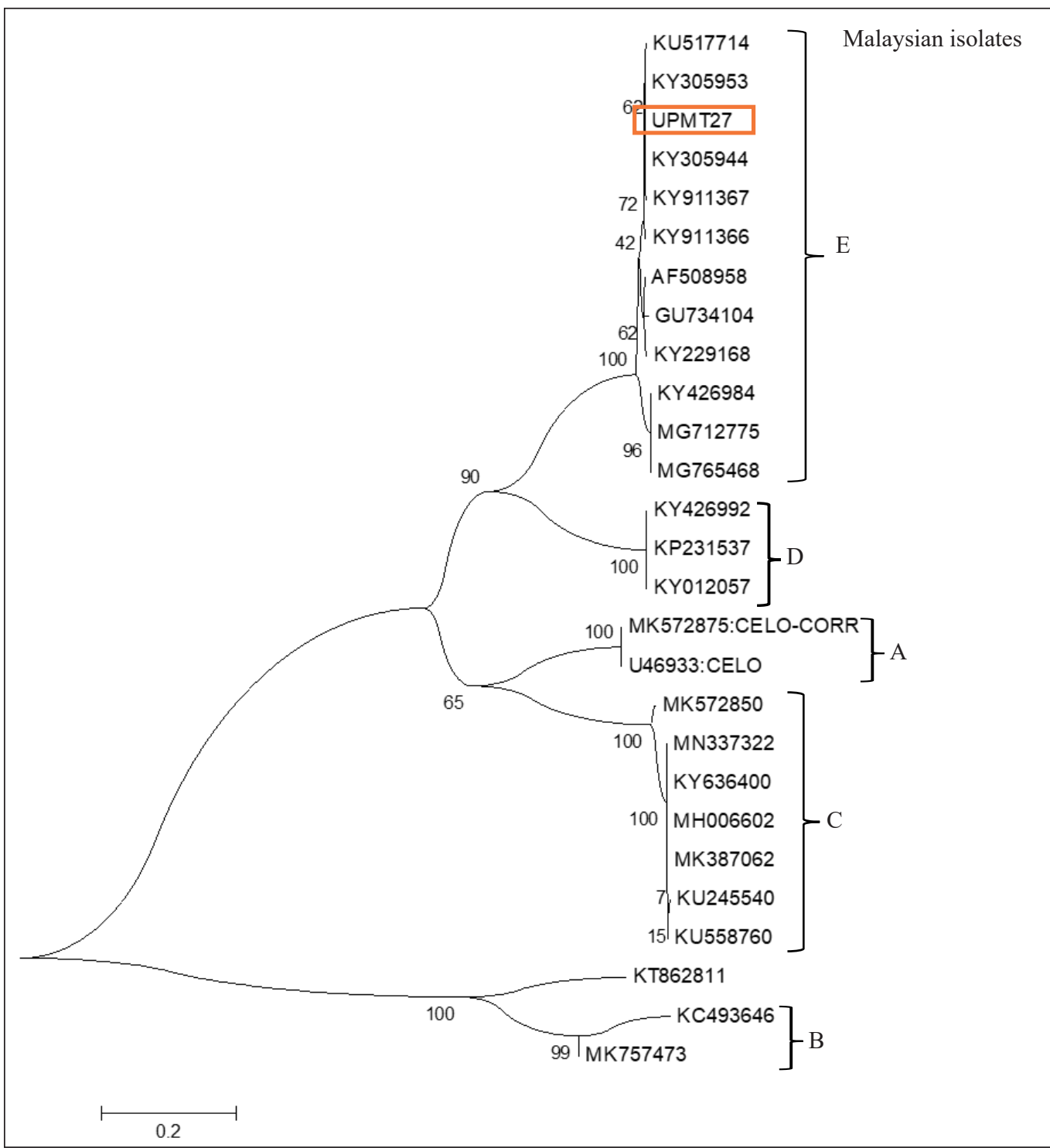

Figure 4. Sequence identity and phylogenetic analysis of partial hexon gene based on the 556 nucleotide bases in Loop 1 region with 27 references isolates are labeled. At major nodes are indicated bootstrap values. UPMT27 is labeled in red box 
(Table 4) at positions 79 (Alanine-alanine), 85 (Serine-serine) 160 (Glutamate- glutamate), 205 (Alanine-alanine) respectively. The result further revealed that there is variation in amino acid substitution between UPMT27 isolate and group B isolates [KC 493646; MK757473] (Marek et al., 2016) at positions 79 (Alanine-valine), 85 (Serine- alanine)

Table 3

Molecular marker substitutions in the fiber protein of UPMT27 and reference FAdV strains retrieved from the NCBI GenBank

\begin{tabular}{|c|c|c|c|c|c|c|c|}
\hline \multirow[t]{2}{*}{$\mathbf{S} / \mathbf{N}$} & \multirow{2}{*}{$\begin{array}{l}\text { Accession } \\
\text { Number }\end{array}$} & \multirow{2}{*}{ Group* } & \multirow{2}{*}{ Serotypes } & \multicolumn{3}{|c|}{$\begin{array}{c}\text { Amino acid (aa) } \\
\text { substitution and position }\end{array}$} & \multirow[t]{2}{*}{ Reference } \\
\hline & & & & 72 & 101 & 125 & \\
\hline 1 & KT862811 & $\mathrm{E}$ & Strain $8 b$ & $\mathrm{~S}$ & $\mathrm{~A}$ & $\mathrm{G}$ & Marek et al., 2016 \\
\hline 2 & MT233531 & $\mathbf{E}$ & Strain $8 b$ & $\mathrm{~S}$ & A & $\mathrm{G}$ & This study \\
\hline 3 & KU517714 & $\mathrm{E}$ & Strain $8 b$ & $\mathrm{~S}$ & A & $\mathrm{G}$ & Juliana et al., 2014 \\
\hline 4 & KY305953 & $\mathrm{E}$ & Strain $8 b$ & $\mathrm{~S}$ & $\mathrm{~A}$ & G & Norfitriah, 2018 \\
\hline 5 & KY305955 & $\mathrm{E}$ & Strain $8 b$ & $\mathrm{~S}$ & $\mathrm{~A}$ & G & Norfitriah, 2018 \\
\hline 6 & KY305954 & $\mathrm{E}$ & Strain $8 b$ & $\mathrm{~S}$ & $\mathrm{~A}$ & G & Norfitriah, 2018 \\
\hline 7 & KY305956 & $\mathrm{E}$ & Strain $8 b$ & $\mathrm{~S}$ & A & $\mathrm{G}$ & Norfitriah, 2018 \\
\hline 8 & KY305950 & $\mathrm{E}$ & Strain $8 b$ & $\mathrm{~S}$ & $\mathrm{~A}$ & G & Norfitriah, 2018 \\
\hline 9 & KY305957 & $\mathrm{E}$ & Strain $8 b$ & $\mathrm{~S}$ & A & $\mathrm{G}$ & Norfitriah, 2018 \\
\hline 10 & MF577036 & $\mathrm{E}$ & Strain $8 b$ & $\mathrm{~S}$ & $\mathrm{~A}$ & $\mathrm{~V}$ & Unpublished \\
\hline 11 & GU734104 & $\mathrm{E}$ & Strain $8 b$ & $\mathrm{~S}$ & $\mathrm{~A}$ & G & Grgić et al., 2011 \\
\hline 12 & MG712775 & $\mathrm{E}$ & Strain $8 b$ & $\mathrm{~S}$ & $\mathrm{~A}$ & V & Unpublished \\
\hline 13 & KT037704 & $\mathrm{E}$ & Strain $8 b$ & $\mathrm{~S}$ & A & $\mathrm{G}$ & Unpublished \\
\hline 14 & KT037705 & $\mathrm{E}$ & Strain $8 b$ & $\mathrm{~S}$ & A & G & Unpublished \\
\hline 15 & КT037708 & $\mathrm{E}$ & Strain $8 b$ & $\mathrm{~S}$ & A & G & Unpublished \\
\hline 16 & КT037709 & $\mathrm{E}$ & Strain $8 b$ & $\mathrm{~S}$ & A & G & Unpublished \\
\hline 17 & KР231537 & $\mathrm{D}$ & $*$ & A & $\mathrm{G}$ & $\mathrm{D}$ & Slaine et al., 2016 \\
\hline 18 & KM096545 & $\mathrm{D}$ & $*$ & A & G & $\mathrm{D}$ & Zhao et al., 2015 \\
\hline 19 & KU746335 & $\mathrm{D}$ & $*$ & A & G & $\mathrm{D}$ & Unpublished \\
\hline 20 & KU558760 & $\mathrm{C}$ & Strain 4 & G & $\mathrm{D}$ & G & Unpublished \\
\hline 21 & MK572850 & $\mathrm{C}$ & Strain 4 & $\mathrm{~S}$ & $\mathrm{D}$ & G & Unpublished \\
\hline 22 & KU991797 & $\mathrm{C}$ & Strain 4 & $\mathrm{~S}$ & $\mathrm{D}$ & G & Unpublished \\
\hline 23 & HE608155 & B & Strain 5 & $\mathrm{~T}$ & $\mathrm{G}$ & $\mathrm{G}$ & Marek et al., 2012 \\
\hline 24 & MG953201 & $\mathrm{B}$ & Strain 5 & $\mathrm{~T}$ & G & G & Unpublished \\
\hline 25 & FR872928 & $\mathrm{B}$ & Strain 5 & $\mathrm{~T}$ & G & $\mathrm{P}$ & Marek et al., 2012 \\
\hline 26 & KC493646 & $\mathrm{B}$ & Strain 5 & $\mathrm{~T}$ & G & $\mathrm{P}$ & Marek et al., 2013 \\
\hline 27 & FN557183 & $\mathrm{A}$ & Strain 1 & $\mathrm{R}$ & $\mathrm{K}$ & $\mathrm{S}$ & Marek et al., 2010 \\
\hline 28 & U46933 & A & Strain 1 & $\mathrm{R}$ & $\mathrm{K}$ & $\mathrm{S}$ & Chiocca et al., 1996 \\
\hline
\end{tabular}

Note. UPMT27 * Indicates the isolate used in this present study Group*=FAdV grouping (A-E)

$*=$ Non-classified strain 
160 (Glutamate- leucine), 205 (Alanine-arginine) respectively as shown in Table 4. Subsequently, prominent amino acid changes were also observed in other FAdV groups (C, D and E) (Table 4).

Table 4

Molecular marker substitutions in the hexon protein of UPMT27 and reference FAdV strains retrieved from the NCBI GenBank

\begin{tabular}{|c|c|c|c|c|c|c|c|}
\hline \multirow[t]{2}{*}{$\mathrm{S} / \mathrm{N}$} & \multirow{2}{*}{$\begin{array}{l}\text { Accession } \\
\text { Number }\end{array}$} & \multirow[t]{2}{*}{ Group* } & \multirow[t]{2}{*}{ Serotypes } & \multicolumn{3}{|c|}{$\begin{array}{l}\text { Amino acid (aa) } \\
\text { substitution and position }\end{array}$} & \multirow[t]{2}{*}{ Reference } \\
\hline & & & & 85 & 160 & 205 & \\
\hline 1 & KT862811 & $\mathrm{E}$ & Strain $8 b$ & A & $\mathrm{L}$ & $\mathrm{V}$ & Marek et al.,2016 \\
\hline 2 & MT233532 & $\mathbf{E}$ & Strain $8 b$ & $\mathbf{S}$ & $\mathrm{E}$ & A & This study \\
\hline 3 & KU517714 & $\mathrm{E}$ & Strain $8 b$ & $\mathrm{~S}$ & $\mathrm{E}$ & A & Juliana et al., 2014 \\
\hline 4 & KY911366 & $\mathrm{E}$ & Strain $8 b$ & $\mathrm{~S}$ & $\mathrm{E}$ & A & Norfitriah, 2018 \\
\hline 5 & KY911367 & $\mathrm{E}$ & Strain $8 b$ & $\mathrm{~S}$ & $\mathrm{E}$ & A & Norfitriah, 2018 \\
\hline 6 & KY305953 & $\mathrm{E}$ & Strain $8 b$ & $\mathrm{~S}$ & $\mathrm{E}$ & A & Norfitriah, 2018 \\
\hline 7 & KY305944 & $\mathrm{E}$ & Strain & $\mathrm{S}$ & $\mathrm{E}$ & A & Norfitriah, 2018 \\
\hline 8 & GU734104 & $\mathrm{E}$ & Strain $8 b$ & $\mathrm{~S}$ & $\mathrm{E}$ & A & Grgić et al., 2011 \\
\hline 9 & KY426984 & $\mathrm{E}$ & Strain $8 b$ & $\mathrm{~S}$ & $\mathrm{E}$ & A & Niu et al., 2016 \\
\hline 10 & MG712775 & $\mathrm{E}$ & Strain $8 b$ & $\mathrm{~S}$ & $\mathrm{E}$ & A & Unpublished \\
\hline 11 & MG765468 & $\mathrm{E}$ & Strain $8 b$ & $\mathrm{~S}$ & $\mathrm{E}$ & A & Unpublished \\
\hline 12 & KY229168 & $\mathrm{E}$ & Strain $8 b$ & $\mathrm{~S}$ & $\mathrm{E}$ & A & Unpublished \\
\hline 13 & AF508958 & $\mathrm{D}$ & Strain -9 & $\mathrm{~S}$ & $\mathrm{E}$ & A & Meulemans et al., 2004 \\
\hline 14 & KY426992 & $\mathrm{D}$ & $*$ & $\mathrm{~V}$ & $\mathrm{~K}$ & A & Unpublished \\
\hline 15 & KP231537 & $\mathrm{D}$ & $*$ & $\mathrm{~V}$ & $\mathrm{~K}$ & A & Slaine et al., 2016 \\
\hline 16 & KY012057 & $\mathrm{D}$ & $*$ & $\mathrm{~V}$ & $\mathrm{~K}$ & A & Unpublished \\
\hline 17 & MN337322 & $\mathrm{C}$ & Strain 4 & $\mathrm{~V}$ & Q & A & Unpublished \\
\hline 18 & KU245540 & $\mathrm{C}$ & Strain 4 & $\mathrm{~V}$ & Q & $\mathrm{E}$ & Unpublished \\
\hline 19 & KY636400 & $\mathrm{C}$ & Strain 4 & $\mathrm{~V}$ & Q & A & Unpublished \\
\hline 20 & MH006602 & $\mathrm{C}$ & Strain 4 & $\mathrm{~V}$ & Q & A & Unpublished \\
\hline 21 & MK572850 & $\mathrm{C}$ & Strain 4 & $\mathrm{~V}$ & $\mathrm{R}$ & A & Unpublished \\
\hline 22 & MK387062 & $\mathrm{C}$ & Strain 4 & $\mathrm{~V}$ & Q & A & Unpublished \\
\hline 23 & KU558760 & $\mathrm{C}$ & Strain 4 & $\mathrm{~V}$ & Q & A & Unpublished \\
\hline 24 & MK572875 & $\mathrm{A}$ & * & $\mathrm{V}$ & Q & A & Schachner et al., 2019 \\
\hline 25 & U46933 & A & Strain 1 & $\mathrm{~V}$ & Q & A & Chiocca et al., 1996 \\
\hline 26 & KC493646 & $\mathrm{B}$ & Strain 5 & $\mathrm{~A}$ & $\mathrm{~L}$ & $\mathrm{R}$ & Marek et al., 2016 \\
\hline 27 & MK757473 & $\mathrm{B}$ & Strain 5 & A & $\mathrm{L}$ & A & Unpublished \\
\hline
\end{tabular}

Note. UPMT27 * Indicate the isolate use in this present study Group*= FAdV grouping (A-E)

$*=$ Non-classified strain 


\section{DISCUSSION}

On a global scale, an incessant outbreak of FAdV has been reported, predominantly within the last 15 years (Schachner et al., 2019). To date, at least one, but more often a combination of more than one FAdV associated condition has been reported from every continent. The first cases of FAdV in Asian continent was reported by Hair-bejo, 2005 from the outbreak in commercial farm in Perak, Malaysia in 2004 and serotype $8 \mathrm{~b}$ of group E is the predominant etiological agent of IBH which is an economically important disease for the poultry industry (Majdi \& Hair-Bejo, 2015).

The PCR result showed that DNA fragments of the expected lengths of the fiber (882 bp) and hexon genes (2900 bp) were successfully amplified (Figure $1 \& 2$ ). This indicated the presence of the virus in the CELs. Also confirmed that CELs derived from embryonated eggs was a sensitive medium for the isolation and propagation of FAVs.

The phylogenetic analysis of the $588 \mathrm{nt}$ bases of the fiber gene showed that UPMT27 was closely related to Malaysian isolates (KU517714, KY305954, KY305955, and KY305950) (Juliana et al., 2014; Norfitriah, 2018) (Figure 3). Similarly, high nucleotide identity was also observed ( $\mathrm{E}$ value $=0,99 \%$ identity) (Norfitriah, 2018). These results showed that UPMT27 shared common ancestors with FAdV serotypes $8 \mathrm{~b}$ under group E which were the predominant serotypes of FAdV causing IBH in Asian continent

The multiple sequence alignment of the fiber and hexon sequences had categorized the FAdV references sequences into 5 diverse divisions. From the phylogenetic tree it has been observed that FAdV strain 7, 8a, and $8 \mathrm{~b}$ are classified from the same ancestor under group E.

This topology agreed with the latest ICTV classification of FAdV with 5 independent clusters designated as Subgroup A-E.

Correspondingly, the phylogenetic analysis of the $556 \mathrm{nt}$ bases of the hexon gene indicated that UPMT27 was clustered phylogenetically with the Malaysian isolates KU517714, KY305954, KY305955, and KY305950) (Juliana et al., 2014; Norfitriah, 2018). Nucleotide identity was also consistent with the Malaysian isolates (KU517714, KY305954, KY305955, and KY305950) (Juliana et al., 2014; Norfitriah, 2018) (E value $=0,99 \%$ identity). It also shared common ancestors with FAdV serotypes $8 \mathrm{~b}$ under group E which were the major serotypes of FAdV causing IBH in Asian continent.

Amino acids changes in the fiber and the hexon genes due to viral adaptation in the primary cell line played vital roles in virus attenuation (Shah et al., 2017). We postulated that amino acids changes might be considered as virus makers for pathogenecity. This agreed with the work reported by Zhang et al. (2018) which showed that amino acid differences in the fiber gene knob domain as well as in the hexon gene L1 loop domain were implicated in the differences in tissue tropism and virulence for human and canine adenoviruses.

The nucleotide sequencing results demonstrated that the UPMT27 isolate was genetically related to Malaysian isolates in both fiber and hexon genes. Multiple sequence 
alignment results showed that there was no amino acid difference in the fiber gene between UPMT27 and Malaysian isolates exhibit similar amino acid substitution at positions 72 (Serine-serine), 101 (Alanine -alanine) and 125 (Glycine-glycine) respectively (Table 3). Hence, the amino acids similarities in the fiber gene between UPMT27 and the Malaysian isolates indicated that the result was consistent with the phylogenetic results, which showed that the isolate under study was genetically related to the Malaysian isolates and could also be categorized under serotype $8 \mathrm{~b}$ and group $\mathrm{E}$, the causative agent of inclusion body hepatitis outbreaks in Malaysia.

The amino acid changes were observed between UPMT27 and isolates in group C at different position (Table 3). Hence, these patterns of amino acid changes indicated the genetic variations that existed amongst FAdV isolates and this could be simply suggested as a determinant for pathogenicities differences among FAdV isolates. This result agreed with a previous work done by Ojkic and Nagy (2000) who reported that amino acid changes in the fiber protein alone in FAdV isolates within the same serotype might caused differences in their pathogenicities.

Based on the hexon gene, the results showed similarity between UPMT27 and the Malaysian isolates (Table 4). The consistency of similar amino acid substitution indicated that UPMT27 was genetically related to the Malaysian isolates. In addition, it was observed that there was a difference in amino acid substitution between UPMT27 and KC493646 and MK757473 at position 79 (Alanine-valine), 85 (Serine- alanine) 160 (Glutamateleucine) and 205 (Alanine-arginine) respectively. This finding was expected as KC493646 and MK757473 are classified under serotype B. Nevertheless, the ability to make this distinction that they are not from the same serotype and group is important because not all 12 FAdV serotypes are pathogenic.

\section{CONCLUSION}

This study showed that UPMT27 is closely related to the other Malaysian isolates categorized under subtype $8 \mathrm{~b}$ of group E which is the predominant subtype in Malaysia, causing inclusion body hepatitis outbreaks. In addition, amino acids changes indicated that the isolate under study was evolutionary related with the Malaysian isolates. That emerged as poultry threats in 2005. Our data suggest that molecular and phylogenetic studies based on the fiber and hexon genes may play important roles in characterizing FAdV isolates and identification of virulence markers.

\section{ACKNOWLEDGEMENTS}

This work was funded by the Higher Institute Centre of Excellent (HICoE) grant (6369101) from the Higher Education Ministry of the Malaysian Government. Also, the authors would like to thank the Laboratory of Vaccine and Immunotherapeutics, IBS, Universiti 
Putra Malaysia for allowing us to conduct all the experiments there. The authors would also like to show appreciation to Professor Dr. Soon Guan Tan, formerly Associate Editor of Elsevier Editorial System, Gene, for proofreading the manuscript

\section{REFERENCE}

Chiocca, S., Kurzbauer, R., Schaffner, G., Baker, A., Mautner, V., \& Cotten, M. (1996). The complete DNA sequence and genomic organization of the avian adenovirus CELO. Journal of Virology, 70(5), 2939-2949.

Grgić, H., Yang, D. H., \& Nagy, É. (2011). Pathogenicity and complete genome sequence of a fowl adenovirus serotype 8 isolate. Virus Research, 156(1-2), 91-97. doi: https://doi.org/10.1016/j.virusres.2011.01.002

Grgić, H., Poljak, Z., Sharif, S., \& Nagy, É. (2013). Pathogenicity and cytokine gene expression pattern of a serotype 4 fowl adenovirus isolate. PloS One, 8(10), 1-10. doi: https://doi.org/10.1371/journal. pone.0077601

Grgić, H., Krell, P. J., \& Nagy, É. (2014). Comparison of fiber gene sequences of inclusion body hepatitis (IBH) and non-IBH strains of serotype 8 and 11 fowl adenoviruses. Virus Genes, 48(1), 74-80.

Gupta, A., Popowich, S., Ojkic, D., Kurukulasuriya, S., Chow-Lockerbie, B., Gunawardana, T., ... \& Tikoo, S. K. (2018). Inactivated and live bivalent fowl adenovirus (FAdV8b+ FAdV11) breeder vaccines provide broad-spectrum protection in chicks against inclusion body hepatitis (IBH). Vaccine, 36(5), 744-750. doi: https://doi.org/10.1016/j.vaccine.2017.12.047

Hair-Bejo, M. (2005). Inclusion body hepatitis in a flock of commercial broiler chickens. Journal of Veterinary Malaysia, 17(1), 23-26.

Huang, Q., Ma, X., Huang, X., Huang, Y., Yang, S., Zhang, L., ... \& Xu, C. (2019). Pathogenicity and complete genome sequence of a fowl adenovirus serotype $8 \mathrm{~b}$ isolate from China. Poultry Science, 98(2), 573-580. doi: https://doi.org/10.3382/ps/pey425

James, N. M., \& Edward, J. D. (2011). Fenner's veterinary viriology (4th Edition). San Diego, USA: Academic Press.

Juliana, M. A., Nurulfiza, M. I., Hair-Bejo, M., Omar, A. R., \& Aini, I. (2014). Molecular characterization of fowl adenoviruses isolated from inclusion body hepatitis outbreaks in commercial broiler chickens in Malaysia. Pertanika Journal of Tropical Agriculture Science, 37(4), 483-497.

Li, P. H., Zheng, P. P., Zhang, T. F., Wen, G. Y., Shao, H. B., \& Luo, Q. P. (2017). Fowl adenovirus serotype 4: Epidemiology, pathogenesis, diagnostic detection, and vaccine strategies. Poultry Science, 96(8), 26302640. doi: https://doi.org/10.3382/ps/pex087

Mansoor, M. K., Hussain, I., Arshad, M., \& Muhammad, G. (2011). Preparation and evaluation of chicken embryo-adapted fowl adenovirus serotype 4 vaccine in broiler chickens. Tropical Animal Health and Production, 43(2), 331-338. doi: https://doi.org/10.1007/s11250-010-9694-z

Majdi, A., \& Hair-Bejo, M. (2015, February 23-27). Pathogenicity of Malaysian fowl adenovirus isolates in specific pathogen free chickens. In 10th Proceedings of the Seminar of Veterinary Sciences (pp. 15-20). Faculty of Veterinary Medicine, Universiti Putra Malaysia, Malaysia. 
Marek, A., Kaján, G. L., Kosiol, C., Benkő, M., Schachner, A., \& Hess, M. (2016). Genetic diversity of species Fowl aviadenovirus D and Fowl aviadenovirus E. Journal of General Virology, 97(9), 2323-2332. doi: https://doi.org/10.1099/jgv.0.000519

Marek, A., Kosiol, C., Harrach, B., Kajan, G. L., Schlotterer, C., \& Hess, M. (2013). The first whole genome sequence of a fowl adenovirus B strain enables interspecies comparisons within the genus aviadenovirus. Journal Veterinary Microbiology, 166(1-2), 250-256. doi: https://doi.org/10.1016/j.vetmic.2013.05.017

Marek, A., Schulz, E., Hess, C., \& Hess, M. (2010). Comparison of the fibers of fowl adenovirus A serotype 1 isolates from chickens with gizzard erosions in Europe and a pathogenic reference strains. Journal of Veterinary Diagnostics, 22(6), 937-941. doi: https://doi.org/10.1177/104063871002200613

Marek, A., Nolte, V., Schachner, A., Berger, E., Schlötterer, C., \& Hess, M. (2012). Two fiber genes of nearly equal lengths are a common and distinctive feature of Fowl adenovirus $\mathrm{C}$ members. Veterinary Microbiology, 156(3-4), 411-417. doi: https://doi.org/10.1016/j.vetmic.2011.11.003

McFerran, J. B., \& Smyth, J. A. (2000). Avian adenoviruses. Revue Scientifique Et Technique (International Office of Epizootics), 19(2), 589-601.

Meulemans, G., Couvreur, B., Decaesstecker, M., Boschmans, M., \& van den Berg, T. P. (2004). Phylogenetic analysis of fowl adenoviruses. Journal of Avian Pathology, 33(2), 164-170. doi: https://doi.org/10.1080 /03079450310001652086

Morshed, R., Hosseini, H., Langeroude, A. G., Fard, M. H. B., \& Charkhkar, S. (2017). Fowl adenoviruses $\mathrm{D}$ and $\mathrm{E}$ cause inclusion body hepatitis outbreaks in broilers and broilers breeder pullet flocks. Avian Disease, 61(2), 205-210. doi: https://doi.org/10.1637/11551-120516-Reg.1

Niu, Y. J., Sun, W., Zhang, G. H., Qu, Y. J., Wang, P. F., Sun, H. L., \& Liu, S. D. (2016). Hydropericardium syndrome outbreak caused by fowl adenovirus serotype 4 in China. Journal of General Virology, 97, 2684-2690. doi: https://doi.org/10.1099/jgv.0.000567

Norfitriah, M. S. (2018). Development of live attenuated Fowl adenovirus isolate of Malaysia for future production of vaccine ( $\mathrm{PhD}$ Thesis). Universiti Putra Malaysia, Malaysia.

Norfitriah, M. S., Hair-Bejo. M., Omar, A. R., Aini, I., \& Nurulfiza, M. I. (2018). Molecular detection and pathogenicity of fowl adenovirus isolated from disease outbreak in commercial layer farm. International Journal of Agriculture Sciences and Veterinary Medicine, 6(1), 73-84.

Norina, L., Norsharina, A., Nurnadiah, A., Redzuan, I., Ardy, A., \& Nor-Ismaliza, I. (2016). Avian adenovirus isolated from broiler affected with Inclusion body hepatitis. Malaysian Journal of Veterinary Research, $7(2), 121-126$.

Ojkic, D., \& Nagy, É. (2000). The complete nucleotide sequence of fowl adenovirus type 8. Journal of General Virology, 81(7), 1833-1837.doi: https://doi.org/10.1099/0022-1317-81-7-1833

Pallister, J., Wright, P. J., \& Sheppard, M. (1996). A single gene encoding the fiber is responsible for variations in virulence in the fowl adenoviruses. Journal of Virology, 70(8), 5115-5122.

Popowich, S., Gupta, A., Chow-lockerbie, B., Ayalew, L., Ambrose, N., Ojkic, D., ... \& Suresh, K. (2018). Broad spectrum protection of broiler chickens against inclusion body hepatitis by immunizing their broiler 
breeder parents with a bivalent live fowl adenovirus vaccine. Research in Veterinary Science, 118, $262-$ 269. doi: https://doi.org/10.1016/j.rvsc.2018.03.003

Rux, J. J., \& Burnett, R. M. (2003). Structural and phylogenetic analysis of adenovirus hexons by use of highresolution X-ray crystallographic, molecular modeling, and sequence based methods. Journal of Virology, 77, 9553-9566. doi: 10.1128/JVI.77.17.9553-9566.2003

Schachner, A., Gonzalez, G., Endler, L., Ito, K., \& Hess, M. (2019). Fowl Adenovirus (FAdV) Recombination with Intertypic Crossovers in Genomes of FAdV-D and FAdV-E, Displaying Hybrid Serological Phenotypes. Viruses, 11(12), 1-24. doi: https://doi.org/10.3390/v11121094

Shah, M. S., Ashraf, A., Khan, M. I., Rahman, M., Habib, M., Chughtai, M. I., \& Qureshi, J. A. (2017). Fowl adenovirus: history, emergence, biology and development of a vaccine against hydropericardium syndrome. Archives of Virology, 162(7), 1833-1843. doi: https://doi.org/10.1007/s00705-017-3313-5

Slaine, P. D., Ackford, J. G., Kropinski, A. M., Kozak, R. A., Krell, P. J., \& Nagy, E. (2016). Molecular characterization of pathogenic and non-pathogenic fowl aviadenovirus serotype 11 isolates. Journal of Microbiology, 62(12), 993-1002. doi: https://doi.org/10.1139/cjm-2016-0297

Soumyalekshmi, S., Ajith, M. K., \& Chandraprakash, M. (2014). Isolation of fowl adenovirus in chicken embryo liver cell culture and its detection by hexon gene based PCR. Journal of Science Research and Technology, 2(3), 33-36.

Wang, Z., \& Zhao, J. (2019). Pathogenesis of Hypervirulent Fowl Adenovirus Serotype 4: The Contributions of Viral and Host Factors. Viruses, 11(8), 1-10. doi: https://doi.org/10.3390/v11080741

Zhang, Y., Liu, R., Tian, K., Wang, Z., Yang, X., Gao, D., ... \& Zhao, J. (2018). Fiber2 and hexon genes are closely associated with the virulence of the emerging and highly pathogenic fowl adenovirus 4. Emerging Microbes and Infections, 7(1), 1-10. doi: https://doi.org/10.1038/s41426-018-0203-1

Zhao, J., Zhong, Q. I., Zhao, Y., Hu, Y. X., \& Zhang, G. Z. (2015). Pathogenicity and complete genome characterization of fowl adenoviruses isolated from chickens associated with inclusion body hepatitis and hydropericardium syndrome in China. PloS One, 10(7), 1-14. doi: https://doi.org/10.1371/journal. pone. 0133073 
